\title{
Oral Cancer Awareness among Dental Patients
}

\author{
Barsha Bajracharya ${ }^{1}$, Anita Dahal ${ }^{2}$ and Rajeeb Kumar Deo ${ }^{3}$
}

${ }^{1}$ Oral Pathology, Department of Dentistry, Nepalese Army Institute of Health Sciences, Shree Birendra Hospital, Chhauni, Kathmandu, Nepal

${ }^{2}$ Orthodontics and Dentofacial Orthopaedics, Department of Dentistry, Nepalese Army Institute of Health Sciences, Shree Birendra Hospital, Chhauni, Kathmandu, Nepal

${ }^{3}$ Medical Oncology, Department of Medicine, Nepalese Army Institute of Health Sciences, Shree Birendra Hospital, Chhauni, Kathmandu, Nepal

ABSTRACT
Introduction: The incidence of oral cancer in South Asian countries, including Nepal is increasing
despite the fact that all of its risk factors are modifiable. This can be attributed to lack of awareness
regarding oral cancer and its risk factors among general public. This study was conducted among subjects
attending Dental OPD of a tertiary hospital to assess the knowledge and attitude regarding oral cancer
and also practices of risk factors associated with it.
Methods: This is a questionnaire based cross-sectional study conducted from July 2020 to October 2020 .
Subjects attending Dental OPD of a tertiary hospital in Kathmandu were asked to fill a structured close-
ended Questionnaire. Section one of the questionnaire focused on the demographic data of the subjects,
second part elicited information pertaining to knowledge of oral cancer, third part focused on attitude and
fourth part on practices of participants towards risk factors of oral cancer.
Result: Out of 300 subjects, $65 \%$ were males. Most were in the age group 41 - 50 years and $75.6 \%$ were
literate. Majority mentioned smokeless tobacco as the risk factor, followed by smoking and alcohol.
Regarding signs and symptoms, most of the participants mentioned non-healing ulcer, followed by lump
and pain. Most of the participants responded tongue as the most common site of oral cancer. Majority
answered that oral cancer can be prevented by not chewing tobacco. Among the total, $55.3 \%$ said oral
cancer is non-contagious. Only $25 \%$ had undergone oral examination in the last one year. $31.7 \%$ had
habit of tobacco and / or alcohol.
Conclusions: The awareness level and knowledge about risk factors and early signs of oral cancer in this
cross-section of dental patients were satisfactory.
Key words: awareness; oral cancer; risk factors; tobacco

Correspondence: Barsha Bajracharya, Oral Pathology, Department of Dentistry, Nepalese Army Institute of Health Sciences, Shree Birendra Hospital, Chhauni, Kathmandu, Nepal. Email: dr.barsha.bajracharya@gmail.com

DOI: $10.3126 / \mathrm{mjsbh.v20i2.33507}$

Submitted on: 2020-12-18

Accepted on: 2021-06-21 


\section{INTRODUCTION}

Oral cancer is the sixth most common cancer in the world, with global age-standardised incidence rate of 4.0 cases per 100,000 populations per year and global mortality rate of 1.9 deaths per 100,000 populations per year. ${ }^{1}$ It has high mortality rate and substantially contributes to the global cancer burden. South Asia accounts for one third of the world burden of oral cancer with age - standardised incidence rates of $>10$ cases per 100,000 population per year. ${ }^{2,3}$ Population based cancer registry in Nepal has reported lip and oral cancer as the fifth most common cancer and the second most common cancer among males. ${ }^{2}$ Despite being highly preventable, oral cancer has high mortality rate and substantially contributes to the global cancer burden. ${ }^{4}$

Oral cancer is associated with multiple risk factors and many lifestyle factors. The most significant risk factors are tobacco and alcohol, accounting for $75 \%$ to $90 \%$ of oral cancers. Other risk factors are chronic irritation, human papilloma virus infection, radiation exposure, exposure to UV light, nutritional deficiency, immune suppression and genetic susceptibility. ${ }^{5}$ Most of these risk factors are modifiable. If people know which risk factors they must control or eliminate, oral cancer can be prevented. Despite this, most of the cases of oral cancer, and specially the ones in developing countries, do not present until it has progressed to advanced stages. One of the main reasons for this is lack of knowledge regarding the risk factors and symptoms of oral cancer among the general population. ${ }^{6}$

In Nepal, studies have shown that level of knowledge regarding risk factors of oral cancer is significantly low. ${ }^{7,8}$ In order to fill this gap in knowledge, it is important that studies be conducted to asses the level of knowledge of oral cancer so that various educational programs and preventive measures can be implemented. This would help decrease the incidence of oral cancer and also help in early detection, which would ultimately decrease morbidity and mortality associated with it. ${ }^{9,10}$ The present study was conducted to assess the knowledge and attitude regarding oral cancer and also practices of risk factors among patients attending dental OPD of a tertiary level hospital in Kathmandu, Nepal.

\section{METHODS}

This is a cross-sectional questionnaire based study conducted among the subjects attending Dental OPD of Shree Birendra Hospital and Trichandra Military Hospital, Kathmandu, Nepal from July 2020 to October 2020. Permission was taken from Institution Review Committee of the institute. The subjects were army personnels and their family members, who were in age group of 18 to 60 years. They were included in the study after taking written consent. Mentally challenged patients and patients who were not willing to participate were excluded from the study. Convenience sampling method was used. The questionnaire was structured, closeended, self-administered, written in English and then translated into regional language (Nepalese). Section one of the questionnaire focused on the demographic data of the subjects. The second part elicited information pertaining to knowledge regarding oral cancer. The third part focused on attitude towards oral cancer. The fourth part contained questions regarding practices of participants towards risk factors of oral cancer. The questionnaire was first given to 30 subjects for clarity and modification was made based on the response. Then the final questionnaire was administered to the subjects in the waiting room of the Department. After collecting data, it was entered in MS excel sheet and analysed in SPSS version 23 statistical software by descriptive statistics. Frequency distribution of demographic data and the correct responses were analysed and tabulated.

\section{RESULT}

A total of 300 subjects participated in this study. Out of these, 195 (65\%) were males and 105 (35\%) were females (Table 1). Majority of participants were in the age group 41 - 50 years $(104,34.6 \%)$, followed by $31-40$ years $(84,28.0 \%)$ and $51-60$ years $(67,22.3 \%)$ (Table 1). Regarding level of education (Figure 1), majority of them were literate $(227,75.6 \%)$. Among the literate participants, most $(113,33.6 \%)$ were educated till $10^{\text {th }}$ standard. Only 12 had bachelor's degree. There were 73 (24.3\%) study participants who were illiterate. 
Table 1. Demographic data $(\mathrm{N}=300)$

\begin{tabular}{|l|l|r|r|}
\hline \multicolumn{2}{|c|}{ Demographic parameters } & $\begin{array}{r}\text { Frequency } \\
(\mathrm{N})\end{array}$ & $\begin{array}{r}\text { Percentage } \\
(\%)\end{array}$ \\
\hline Sex & Male & 195 & $65.0 \%$ \\
& Female & 105 & $35.0 \%$ \\
\hline Age & $18-20$ & 16 & $5.3 \%$ \\
& $21-30$ & 29 & $9.7 \%$ \\
& $31-40$ & 84 & $28.0 \%$ \\
& $41-50$ & 104 & $34.6 \%$ \\
& $51-60$ & 67 & $22.3 \%$ \\
\hline
\end{tabular}

Regarding knowledge about the risk factors of oral cancer (Table 2), majority of the participants (144, $48 \%$ ) knew only one risk factor and 69 (23.0\%) knew two or more risk factors. 87 (29.0\%) did not know about any risk factors. Among those who knew, majority mentioned smokeless tobacco as the

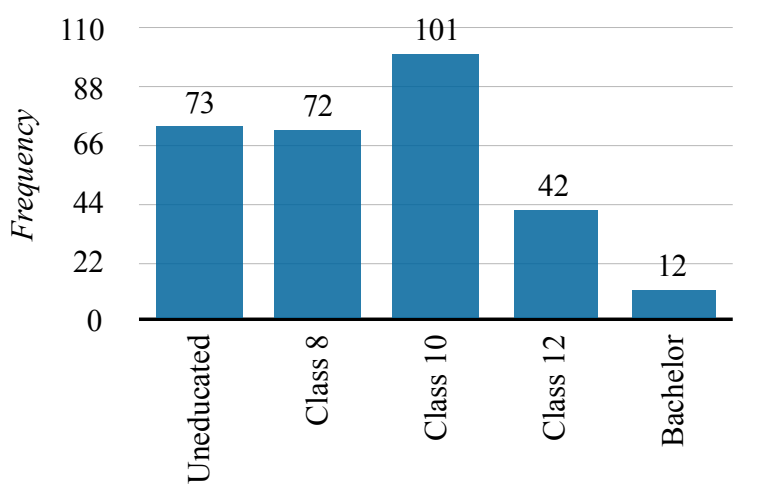

Education

Figure 1. Education level of the participants $(\mathrm{N}=300)$

risk factor (73 single response and 43 multiple responses), followed by smoking (48 single response and 57 multiple response), alcohol (12

Table 2. Knowledge regarding risk factors, signs and sites of oral cancer among participants $(\mathrm{N}=300)$

\begin{tabular}{|c|c|c|c|c|}
\hline SN & Questions & Responses & Frequency (N) & Percentage $(\%)$ \\
\hline \multirow[t]{4}{*}{1} & \multirow[t]{4}{*}{$\begin{array}{l}\text { Knowledge of } \\
\text { risk factors of } \\
\text { oral cancer }\end{array}$} & $\begin{array}{l}\text { (i) Knew one risk factor } \\
\text { - Smokeless tobacco } \\
\text { - Smoking } \\
\text { - Alcohol } \\
\text { - Family history }\end{array}$ & $\begin{array}{l}144 \\
\cdot 73 \\
\cdot 48 \\
\cdot 12 \\
\text { - } 11\end{array}$ & $\begin{array}{l}48 \% \\
\cdot 24.3 \% \\
\cdot 16.0 \% \\
\cdot 4.0 \% \\
\cdot 3.6 \%\end{array}$ \\
\hline & & $\begin{array}{l}\text { (ii) Knew two or more risk factors } \\
\text { - Smoking tobacco }+ \text { alcohol } \\
\text { - Smokeless tobacco }+ \text { smoking tobacco } \\
\text { - Smokeless tobacco }+ \text { alcohol } \\
\text { - Smokeless tobacco }+ \text { smoking tobacco }+ \text { alcohol }\end{array}$ & $\begin{aligned} 69 \\
\cdot 26 \\
\cdot 20 \\
\cdot 12 \\
\cdot 11\end{aligned}$ & $\begin{array}{l}23.0 \% \\
\cdot 8.6 \% \\
\cdot 6.6 \% \\
\cdot 4.0 \% \\
\cdot 3.6 \%\end{array}$ \\
\hline & & (iii) Did not know any risk factors & 87 & $29.0 \%$ \\
\hline & & Total & 300 & $100 \%$ \\
\hline \multirow[t]{4}{*}{2} & \multirow[t]{4}{*}{$\begin{array}{l}\text { Knowledge of } \\
\text { signs of oral } \\
\text { cancer }\end{array}$} & $\begin{array}{l}\text { (i) Knew one signs and symptoms } \\
\text { - Non-healing ulcer } \\
\text { - Lump } \\
\text { - Pain }\end{array}$ & $\begin{array}{l}78 \\
\cdot 42 \\
\cdot 24 \\
\cdot 12\end{array}$ & $\begin{array}{l}26.0 \% \\
\cdot 14.0 \% \\
\cdot-8.0 \% \\
\cdot 4.0 \%\end{array}$ \\
\hline & & $\begin{array}{l}\text { (ii) Knew two or more signs and symptoms } \\
\text { - Non-healing Ulcer + pain } \\
\text { - Non-healing Ulcer + lump }\end{array}$ & $\begin{aligned} 58 & \\
\cdot & 37 \\
\cdot & 21\end{aligned}$ & $\begin{array}{l}19.3 \% \\
\cdot 12.3 \% \\
\cdot 7.0 \%\end{array}$ \\
\hline & & (iii) Did not know any signs and symptoms & 164 & $54.6 \%$ \\
\hline & & Total & 300 & $100 \%$ \\
\hline \multirow[t]{4}{*}{3} & \multirow[t]{4}{*}{$\begin{array}{l}\text { Knowledge of } \\
\text { sites of oral } \\
\text { cancer }\end{array}$} & $\begin{array}{l}\text { (i) Knew only one site } \\
\text { - Tongue } \\
\text { - Gingiva } \\
\text { - Buccal mucosa } \\
\text { - Lips }\end{array}$ & $\begin{array}{r}217 \\
\cdot 72 \\
\cdot 67 \\
\cdot 48 \\
\cdot 30\end{array}$ & $\begin{array}{l}72.3 \% \\
\cdot 24.0 \% \\
\cdot 22.3 \% \\
\cdot 16.0 \% \\
\cdot 10.0 \%\end{array}$ \\
\hline & & $\begin{array}{l}\text { (ii) Knew two or more sites } \\
\text { - Tongue }+ \text { gingiva } \\
\text { - Tongue }+ \text { buccal mucosa } \\
\text { - Gingiva }+ \text { buccal mucosa } \\
\text { - Tongue }+ \text { gingiva }+ \text { buccal mucosa }\end{array}$ & $\begin{aligned} 57 & \\
\cdot & 18 \\
\cdot & 16 \\
\cdot & 6 \\
\cdot & 17\end{aligned}$ & $\begin{array}{l}19.0 \% \\
\cdot \quad 6.0 \% \\
\cdot 5.3 \% \\
\cdot 2.0 \% \\
\cdot 5.6 \%\end{array}$ \\
\hline & & (iii) Did not know any site & 26 & $8.6 \%$ \\
\hline & & Total & 300 & $100 \%$ \\
\hline
\end{tabular}


Table 3. Attitude of patients towards oral cancer

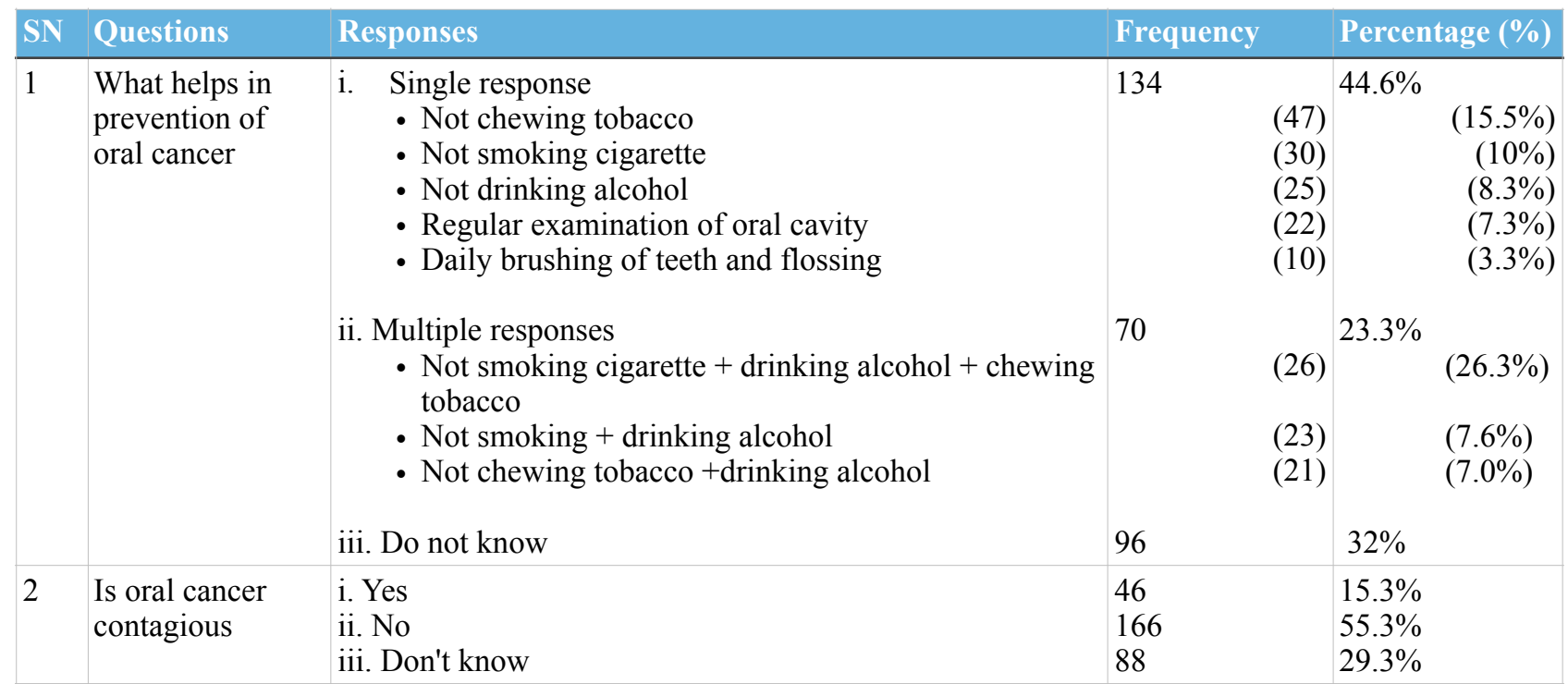

single response and 49 multiple responses) and family history (11 single responses).

As for signs of oral cancer (Table 2), more than half of the participants $(164,54.6 \%)$ did not know any. 78 knew only one and 58 knew two or more signs and symptoms. Among those who knew, most mentioned non - healing ulcer (42 single responses and 58 multiple responses), followed by lump (24 single responses and 21 multiple responses) and pain (12 single responses and 37 multiple responses).

Table 4. Practices of the participants

\begin{tabular}{|c|c|c|c|}
\hline SN & Questions & Responses & $\begin{array}{c}\text { Frequency } \\
(\%)\end{array}$ \\
\hline \multirow[t]{2}{*}{1} & \multirow{2}{*}{$\begin{array}{l}\text { Oral } \\
\text { examination } \\
\text { in last one } \\
\text { year }\end{array}$} & No & $225(75.0 \%)$ \\
\hline & & $\begin{array}{l}\text { Yes } \\
\text { i. Specific oral } \\
\text { problems } \\
\text { ii. Routine } \\
\text { physical examination } \\
\text { iii. Routine dental } \\
\text { examination }\end{array}$ & $\begin{array}{l}75(25.0 \%) \\
\cdot 73 \\
(24.3 \%) \\
\cdot 0(0.0 \%) \\
.2(0.6 \%)\end{array}$ \\
\hline \multirow[t]{5}{*}{2} & \multirow[t]{5}{*}{ Habit } & Smoking tobacco & $20(6.7 \%)$ \\
\hline & & Chewing tobacco & $46(15.3 \%)$ \\
\hline & & Drinking alcohol & $6(2.0 \%)$ \\
\hline & & $\begin{array}{l}\text { Multiple habits } \\
\text { - Smoking and } \\
\text { chewing tobacco } \\
\text { - Chewing tobacco } \\
\text { and drinking } \\
\text { alcohol }\end{array}$ & $\begin{array}{l}33(7.7 \%) \\
\cdot 8(2.7 \%) \\
\text { - } 15(5.0 \%)\end{array}$ \\
\hline & & No habit & $205(68.3 \%)$ \\
\hline
\end{tabular}

In regards to knowledge of sites of oral cancer (Table 2$)$, majority $(217,72.3 \%)$ knew only one site, 57 (19.0\%) knew two or more sites whereas 26 $(8.6 \%)$ did not know any site. Most of the participants responded tongue as the commonest site of oral cancer (72 single response and 51 multiple response), followed by gingiva (67 single response and 41 multiple response), buccal mucosa (48 single response and 39 multiple responses) and lips (30 single response). $8.6 \%$ did not have knowledge regarding site of oral cancer.

Regarding attitude of the participants towards oral cancer (Table 3), when asked what helps in prevention of oral cancer, majority answered not chewing tobacco (47 single response and 47 multiple responses) followed by not smoking

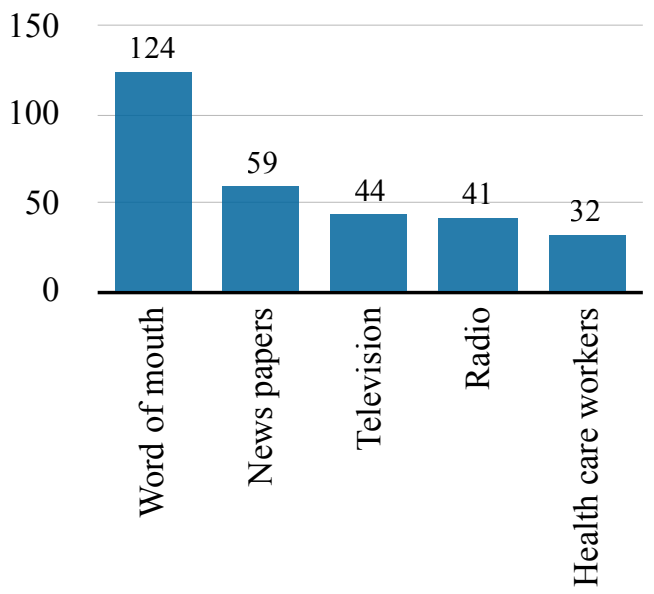

Figure 2. Source of information regarding oral cancer 
cigarette, not drinking alcohol and regular oral examination. When asked if oral cancer is contagious, majority said no (166, 55.3\%) while 88 said that they do not know (Table 5).

As for practices of the study participants (Table 4), only $75(25 \%)$ had undergone oral examination in the last one year. Out of which $73(24.3 \%)$ had gone for specific oral problems and two for routine dental examination. Majority $(225,75 \%)$ had not gone for oral examination. Regarding habits, $31.7 \%$ had habit. Out of which $6.7 \%$ had habit of tobacco smoking, $15.3 \%$ had habit of chewing tobacco and $2 \%$ had habit of drinking alcohol. $2.7 \%$ had habit of smoking and chewing tobacco. $5 \%$ had the habit of chewing tobacco and drinking alcohol.

Finally when asked regarding their source of information regarding oral cancer, majority said word of mouth, followed by newspaper, television and radio. Only $10.6 \%$ received information regarding oral cancer from health care workers (Figure 2).

\section{DISCUSSION}

Oral cancer is one of the commonest cancers in low to middle income countries in South Asia. ${ }^{11}$ Considering the fact that all the risk factors of oral cancer are modifiable, oral cancer should be preventable. But the incidence of oral cancer in these regions is high due to popularity of tobacco habits there. This can be attributable to lack of awareness among the general public regarding oral cancer and its risk factors. ${ }^{8}$ Not many studies have been conducted in Nepal to evaluate patients' knowledge regarding oral cancer and its risk factors. The present study was conducted among patients attending Dental OPD of a tertiary hospital to assess the knowledge and attitude regarding oral cancer and also practices of risk factors.

In this study, more than three fourth of the participants were literates. Among the literate participants, most were educated only till $10^{\text {th }}$ standard. Knowledge regarding risk factors of oral cancer among participants was satisfactory. Only $29 \%$ did not know any risk factors. Majority had correctly identified tobacco as the risk factor of oral cancer, which is consistent with the study conducted by Bajracharya D et al. in Kathmandu, Nepal. This can be due to various anti-tobacco advertisements in media and in the covers of tobacco, and restrictions of use in public places. In a study conducted by Kaverappa $\mathrm{V}$ et al. in Karnataka, India, majority of the participants $(73.5 \%)$ were aware of risk factors of oral cancer, out of which most mentioned tobacco chewing as risk factor of oral cancer, which is similar to our study. ${ }^{12}$ In a study conducted by Crastha $\mathrm{S}$ et al. in rural area in Bangalore, India, majority $(37.6 \%)$ did not know any risk factors of oral cancer and among those who knew the risk factors of oral cancer, most $(27.6 \%)$ knew smokeless tobacco as the risk factor. ${ }^{13}$ According to WHO, tobacco smoking and alcohol are the dominant risk factors of oral cancer and are strongly synergistic. Alcohol and tobacco account for more than $80 \%$ of the disease burden of oral cancer. Many studies have shown that tobacco smoking in any form increases the risk of oral cancer by two fold to ten fold. ${ }^{14}$ This risk increases significantly with duration and frequency of tobacco use. Also, risk is consistently lower in former smoker than in current smoker and with increase in number of years of quitting, risk decreases. ${ }^{15}$ None of the participants in the present study knew betel quid chewing, human papilloma virus, radiation, exposure to sunlight and lower consumption of fruits and vegetable as risk factors, which are all proven by IARC as risk factors of oral cancer. Areca nut or betel nut is now regarded as a type 1 carcinogen. ${ }^{16}$ It is chewed raw, dried, roasted or as part of betel quid mostly in south Asia, including Nepal, and is contributing significantly. High consumption of fruits and vegetable is associated with a reduction of 40 to $50 \%$ in the risk of oral cancer. ${ }^{17}$ Most of these risk factors are preventable. Spreading awareness regarding risk factors of oral cancer and prevention efforts can definitely help reduce the incidence of oral cancer. ${ }^{18}$

Clinical presentation of oral cancer exhibits substantial variation and can be non-specific, which can hinder diagnosis. Most of the patients with oral cancer presents with signs and symptoms of locally advanced disease. In the present study, majority (54.6\%) did not have knowledge regarding signs of oral cancer. Among the ones who knew, most knew non-healing ulcer as the sign of oral cancer. No one knew white / red patch, difficulty in speaking or difficulty in swallowing as the sign of oral cancer. 
According to WHO, mucosal growth, ulceration, pain, difficulty with speaking and neck swelling are the commonest presentation of oral cancer. ${ }^{14}$ In a study regarding awareness of oral cancer conducted by Agrawal $\mathrm{M}$ et al. in Gorakhpur, India, abnormal tissue growth, non healing oral ulcers / sores and reduced mouth opening were the symptoms known by most (more than $60 \%$ respondents). $39.8 \%$ subjects knew presence of red / white spots and $23.2 \%$ knew undue loss of teeth as an early symptom in their study. ${ }^{19}$ In contrast to our study, in a study conducted by Gopal $\mathrm{K}$ et al. in a dental college in Karnataka, India, high percentage (60\%) of the participants had knowledge about the signs and symptoms of oral cancer. ${ }^{20}$

In the present study, majority knew tongue as the site of oral cancer, followed by gingiva, buccal mucosa and lips. No one responded palate and floor of mouth as site of oral cancer. In a similar study conducted by Kaverappa $\mathrm{V}$ et al. in Karnataka, India, majority knew cheek as the site of OC followed by tongue and floor of mouth. ${ }^{12} \mathrm{~A}$ systematic review by Shrestha AD et al. reported buccal mucosa as the commonest site of oral cancer in low and middle income countries. ${ }^{11}$ Epidemiological study by Sharma $\mathrm{S}$ et $\mathrm{al} .{ }^{21}$ in Nepal also reported buccal mucosa as the common site of oral cancer. This can be attributed to habitual placement of chewing tobacco in the area of buccal mucosa. Since in our study, only minority of the participants thought that buccal mucosa is a common site of oral cancer, the knowledge regarding the site of oral cancer in our study can be considered inadequate.

Regarding attitude of the participants towards oral cancer, majority answered that not chewing tobacco and not smoking cigarette helps in prevention of oral cancer. Most of the participants correctly answered that oral cancer is not contagious. In a study conducted by Chaulagain DD et al. in Biratnagar, Nepal, $65.6 \%$ of participants responded that oral cancer could be prevented by avoiding consumption of tobacco, which is similar to our study. Also $62.2 \%$ of participants in the same study thought consumption of fruits and vegetable can prevent oral cancer. ${ }^{22} \mathrm{~A}$ study by Marron et al. ${ }^{23}$ regarding cessation of smoking tobacco and reversal of head and neck cancer, reported that quitting tobacco smoking for one to four years resulted in head and neck cancer reduction. They reported that after 20 years of cessation of tobacco smoking, the risk reached the level of never smokers.

As for practices of the study participants, majority had not gone for oral examination in the last one year. None of the participants had done oral examination as a part of general physical examination. In a similar study conducted by Kaverappa V et al., majority of the participants had not gone or oral examination in the last one year, which is similar to our study. ${ }^{12}$ Regular oral examination can help to identify oral cancer cases in early stage. Early diagnosis may result in less aggressive treatment, which in turn helps to improve the quality of life of patient and also overall five year survival rate. ${ }^{24}$ Therefor it is important to spread awareness among general public regarding the importance of regular oral examination.

Regarding habits, $32.7 \%$ had habit. Out of which $6.7 \%$ had habit of tobacco smoking, $15.3 \%$ had habit of chewing tobacco and $6 \%$ had habit of drinking alcohol. $2.7 \%$ had habit of smoking and chewing tobacco. $5 \%$ had the habit of chewing tobacco and drinking alcohol. A review article by Sinha DN et al. ${ }^{25}$, regarding smokeless tobacco use in Nepal, stated that the prevalence of smokeless tobacco use in Nepal is high, mainly among males and disadvantaged groups, which is attributed to tobacco products being manufactured in unorganised sectors, easy access to various smokeless tobacco products and lack of awareness regarding the hazards of smokeless tobacco. They stated that to achieve reduction in tobacco use in Nepal, tobacco control act should be enforced through a multi-sectoral approach. As for the source of information regarding oral cancer, only $10.6 \%$ of the participants received information form the health care workers. Study by Bajracharya $\mathrm{D}$ et al. ${ }^{26}$ in Nepal reported mass media as the main source of information about oral cancer. Healthcare workers are the ones who are in the position to spread correct information regarding oral cancer. Therefor health care workers must be encouraged to spread awareness regarding oral cancer, especially regarding the risk factors. Various community level programs should also be organised for the same. Our study was limited by 
the fact that it was a single centric study, the result of which may not be generalised to the population of various areas where resources are more limited. Our results need to be further substantiated with larger, more comprehensive and mutli - centric studies in the future.

\section{CONCLUSIONS}

This study has shown that knowledge among participants regarding risk factors and signs and symptoms of oral cancer are satisfactory. However, attitude towards oral cancer and practices regarding risk factors needs improvement. In other to achieve this, there is need for structured awareness programs like inclusion of topic in school textbooks and advertisement in $\mathrm{TV}$, radio and online platforms. Healthcare workers have important responsibility of spreading knowledge that risk factors of oral cancer are modifiable, it is possible to prevent it and early diagnosis helps in better prognosis. This can help in decrease the disease burden of oral cancer. Knowledge can change attitude and attitude can definitely change behaviour of people regarding oral cancer.

To cite this article: Bajracharya B, Dahal A, Deo RK. Oral Cancer Awareness among Dental Patients. MJSBH. 2021;20(2):162-9.

Conflict of Interest: None declared

\section{REFERENCES}

1. Barnes L, Eveson JW, Sidransky D, Reichart P, editors. WHO Classification of Tumours. Pathology and Genetics of Head and Neck Tumours. Lyon: IARC Press; 2005.

2. Population Based Cancer Registry in Nepal. Nepal Health Research Council. NHRC; 2018. Available from: http:// nhrc.gov.np/wp-content/uploads/2019/04/Progress-Interim-_cancer.pdf

3. Wright JM, Vered M. Update from the 4th edition of the World Health Organisation classification of head and neck tumours: Odontogenic and maxillofacial bone tumours. Head Neck Pathol. 2017;11(1):68-77. DOI: https://doi.org/ 10.1007/s12105-017-0794-1

4. Guruaribam V, Sarumathi T. Knowledge and awareness regarding oral cancer among dental patients. Drug Invent Today. 2019;12(3):528-531. Available from: https://jprsolutions.info/article_detail.php?article_id=3297

5. Moreno-López L, Esparza-Gómez G, González-Navarro A, Cerero-Lapiedra R, González-Hernández M, Domínguez-Rojas V. Risk of oral cancer associated with tobacco smoking, alcohol consumption and oral hygiene: A case-control study in Madrid, Spain. Oral Oncol. 2000;36(2):170-4. DOI: https://doi.org/10.1016/ S1368-8375(99)00084-6

6. Warnakulasuriya S. Global epidemiology of oral and oropharyngeal cancer. Oral Oncol. 2009;45(4-5):309-16. DOI: https://doi.org/10.1016/j.oraloncology.2008.06.002

7. Chaulagain D, Parajuli K, Khatiwada B. Oral Cancer : Awareness Among People of Biratnagar. J Nobel Med Coll. 2018;7(1):60-4. DOI: https://doi.org/10.3126/jonmc.v7i1.20850

8. Shrestha AD. Can lay health workers help prevent oral cancer in Nepal? Lancet Oncol. 2017;18(7):e370. DOI: https://doi.org/10.1016/S1470-2045(17)30468-0

9. Shimpi N, Jethwani M, Bharatkumar A, Chyou P, Glurich I, Acharya A. Patient awareness / knowledge towards oral cancer : a cross-sectional survey. BMC Oral Health. 2018;1-10. DOI: https://doi.org/10.1186/s12903-018-0539-x

10. Fotedar S, Bhardwaj V, Manchanda K, Fotedar V, De Sarkar A, Sood N. Knowledge, attitude and practices about oral cancers among dental students in HP Government Dental College, Shimla-Himachal Pradesh. South Asian J cancer. 2015;4(2):65. DOI: https://doi.org/10.4103/2278-330X.155643

11. Shrestha AD, Vedsted P, Kallestrup P, Neupane D. Prevalence and incidence of oral cancer in low-and middleincome countries: A scoping review. Eur J Cancer Care (Engl). 2020;29(2):e13207. DOI: https://doi.org/10.1111/ ecc. 13207 
12. Vishma BK, Shashikantha SK, Sheethal MP, Muniyal AS. Awareness of oral cancer and its risk factors in a rural community in Mandya, Karnataka, India. Int J Community Med Public Heal. 2016;3(1):347-52. DOI: https:// doi.org/10.18203/2394-6040.ijcmph20151589

13. Crastha S, Thangaraj S, Sobagiah RT. Assessment of knowledge, attitude and practices of risk factors of oral cancer among the adult population of rural field practice area of Bangalore Medical College and Research Institute. Int J Community Med Public Heal. 2018;5(2):574-8. DOI: https://doi.org/10.18203/2394-6040.ijcmph20180231

14. IARC Working Group on the Evaluation of Carcinogenic Risks to Humans. Tobacco smoke and involuntary smoking. IARC Monogr Eval Carcinog Risks Hum. 2004;83:1-1438. PMID: 15285078

15. Sankaranarayanan R, Ramadas K, Amarasinghe H, Subramanian S, Johnson N. Oral cancer: Prevention, Early Detection, and Treatment. Cancer: Disease Control Priorities. 3rd ed (Volume 3). Washington DC: The International Bank for Reconstruction and Development / The World Bank; 2015. DOI: https://doi.org/ 10.1596/978-1-4648-0349-9_ch5

16. IARC Working Group on the Evaluation of Carcinogenic Risks to Humans. Betel-quid and Areca-nut Chewing and Some Areca-nut-derived Nitrosamines. Lyon (FR): International Agency for Research on Cancer; 2004. (IARC Monographs on the Evaluation of Carcinogenic Risks to Humans, No. 85.) Available from: https:// www.ncbi.nlm.nih.gov/books/NBK316567/

17. Lucenteforte E, Garavello W, Bosetti C, La Vecchia C. Dietary factors and oral and pharyngeal cancer risk. Oral Oncol. 2009;45(6):461-7. DOI: https://doi.org/10.1016/j.oraloncology.2008.09.002

18. Azhar N, Sohail M, Ahmad F, Fareeha S, Jamil S, Mughal N, et al. Risk factors of Oral cancer-A hospital based case control study. J Clin Exp Dent. 2018;10(4):e396. DOI: https://doi.org/10.4317/jced.54618

19. Agrawal M, Pandey S, Jain S, Maitin S. Oral cancer awareness of the general public in Gorakhpur city, India. Asian Pacific J Cancer Prev. Asian Pacific Organisation for Cancer Prevention; 2012;13(10):5195-9. DOI: https://doi.org/ 10.7314/APJCP.2012.13.10.5195

20. Gopal KS, Duraiselvi P. Awareness and knowledge of oral cancer among dental patients: A survey based questionnaire study. Int J Adv Heal Sci. 2014;1(7):12-5. Available from: https://citeseerx.ist.psu.edu/viewdoc/ download?doi $=10.1 .1 .682 .1510 \&$ rep $=$ rep $1 \&$ type $=$ pdf

21. Sharma S. Prevalence and Epidemiological Variation of Oral Squamous Cell Carcinoma among Population of Central Nepal. J Coll Med Sci. 2019;15(4):267-9. DOI: https://doi.org/10.3126/jcmsn.v15i4.24109

22. Chaulagain DD, Parajuli KP, Khatiwada B. Oral Cancer: Awareness Among People of Biratnagar. J Nobel Med Coll. 2018;7(1):60-4. DOI: https://doi.org/10.3126/jonmc.v7i1.20850

23. Marron M, Boffetta P, Zhang Z-F, Zaridze D, Wünsch-Filho V, Winn DM, et al. Cessation of alcohol drinking, tobacco smoking and the reversal of head and neck cancer risk. Int J Epidemiol. Oxford University Press; 2010;39(1):182-96. DOI: https://doi.org/10.1093/ije/dyp291

24. Awan K. Oral Cancer: Early Detection is Crucial. JIOH. 2014;6(5):1-2. PMCID: PMC4229841

25. Sinha DN, Bajracharya B, Khadka BB, Rinchen S, Bhattad VB, Singh PK. Smokeless tobacco use in Nepal. Indian J Cancer. 2012;49(4):352. 26. DOI: 10.4103/0019-509X.107728

26. Bajracharya D, Gupta S, Sapkota M, Bhatta S. Oral Cancer Knowledge and Awareness in Patients Visiting Kantipur Dental College. J Nepal Health Res Counc. 2018;15(3):247-51. DOI: https://doi.org/10.3126/jnhrc.v15i3.18849 